\title{
THE ORGANIZATION OF MONITORING OF FUTURE TEACHERS' PSYCHOLOGICAL AND PEDAGOGICAL TRAINING IN ESTABLISHMENTS OF PROFESSIONAL AND TECHNICAL EDUCATION
}

\author{
O. Kryvylova
}

У статті теоретично обтрунтовано процес організачії моніторингу психолого-педагогічної підготовки майбутніх викладачів закладів професійно-технічної освіти, який містить п'ять етапів: I етап - иілепокладання та планування дослідження; II етап - розробка інструментарію; III етап - проведення дослідження; IV етап - збирання та обробка результатів; V етап - аналіз та інтерпретація результатів дослідження.

На основі визначених компонентів психолого-педагогічної компетентності, виокремлено три критерії: особистісний, змістово-процесуальний, оцінно-регулятивний. При изьому кожен критерій є сукупністю кількох показників, які характеризують найбільш суттєві й необхідні прояви компонентів психологопедагогічної компетентності майбутніх викладачів закладів професійно-технічної освіти. Обрано діагностичний інструментарій, який дозволяє оцінити рівні сформованості компонентів психологопедагогічної компетентності майбутніх викладачів закладів професійно-технічної освіти за означеними критеріями. Зокрема, діагностичний інструментарій когнітивного компоненту складає: методи тестування: тест Дж. Равена, тест Р. Амтхауера(особистісний критерій: відповідність психофізіологічних особливостей професійним вимогам (психічні процеси: відчуття, сприймання, пам'ять, мислення, уява та увага)); метод тестового контролю, аналіз письмових і усних відповідей (змістовно-процесуальний критерій: теоретичні знання академічної області (гнучкість, міиність, розуміння); опитувальник метакогнітивної включеності у діяльність (оцінно-регулятивний критерій: мета-когнітивні знання (знання суб 'єкта про особисті стратегії навчання), мета-когнітивна оцінка (судження про свої розумові можливості й обмеження, їхня необхідність у конкретній ситуації), мета-когнітивна регуляція (модифікаџіï суб' 'ктом свого мислення).

Розкрито зміст експериментального впровадження методики організації моніторингу психологопедагогічної підготовки майбутніх викладачів закладів професійно-технічної освіти (на прикладі перевірки рівня сформованості когнітивних та мета-когнітивних вмінь, навичок, знань та розумінь, щяо мають місие в оволодінні особливостями психолого-педагогічною діяльністю) та доведено обтрунтованість і адекватність дослідницьких інструментів та надійність отриманих даних.

Запропоноване дослідження дозволяє впливати на вирішення проблем кадрового забезпечення начіонального ринку праці та запобігання трудової міграції на етапі професійної освіти і навчання в иілому, та у контексті набуття здобувачами вищої освіти компетентностей для особистісної та професійної самореалізаціїі кар'єрного зростання впродовж життя зокрема

Ключові слова:викладачі, заклади професійно-технічної освіти, компетентність, методика, моніторинг, психолого-педагогічна підготовка, організація

Copyright (C) 2020, O. Kryvylova. This is an open access article under the CC BY license (http://creativecommons.org/licenses/by/4.0).

\section{Introduction}

The concept of pedagogical education development emphasizes creation of the training base for pedagogical workers of new generation, which system of internal quality support additionally provides requirements to the psychological and pedagogical training [1], that needs control and diagnostics of academic/personal achievements.

A precondition of the innovative pedagogical system's productivity is the correspondence of pedagogical workers' personal-professional level to time requirements. So, the monitoring organization of the psychological and pedagogical training of future teachers of establishments of professional and technical education gains more and more topicality.

\section{Literary review}

Last time the quality monitoring of education as a means for studying educational systems became an object of theoretical studies and at the same time a sphere of pedagogical activity, but the term "monitoring" (means control, observation) is notalways unambiguously interpreted in pedagogical literature and educational practice.It is sometimes used as observation of the educational process productivity; somewhere it is understood as an ordinary pedagogical control; it is used more often in the sense of many-sided study of certain functional indicators of the educational system or its separate elements or subjects of the educational process (quality training monitoring of specialists of a certain profession, material-technical support of educational institutions and 
so on) [2]. Monitoring may be most commonly defined as a constant observation of a certain process for revealing its correspondence to a desirable result or initial condition [3].

Based on the analysis of the methodology of pedagogical measurements and scientific-theoretical grounds of its organization, it has been revealed, that monitoring of the professional training of future specialists is divided in subject-oriented and person-oriented technologies. Thus, subject-oriented may include B. Bloom's taxonomy that covers three main domains of students' activity: cognitivedomain, affectivedomain and psycho-motor domain $[4,5]$. The hierarchy of cognitive purposes, offered by B. Bloom, undoubtedly, favors the formation of rational skills of a higher level in students, but as any theoretical model it needs correction according to requirements of the modern educational activity. L. Anderson and D. Krathwohl offered a renovated variant of B. Bloom's taxonomy, influenced by spread of the Internet and new information-communication technologies [6]. Researchers applied taxonomy as an effective instrument for creating a schedule. L. Anderson and D. Krathwohlreinterpreted two high levels in the hierarchy of educational purposes and changed the original terminology of B. Bloom's taxonomy, having changed nouns for analogous gerunds, in such a way stressing the activity of measured cognitive processes: remembering, understanding, applying, analysing, evaluating, creating [6]. Each taxonomic category corresponds to a certain set of key verbs, helping to formulate expected results and to select questions and tasks at forming schedules. A. Churches presented a new variant of B. Bloom's taxonomy, adapted for students of XXI century «Bloom'sDigitalTaxonomy» [7], according to which cognitive processes, connected with information actions, for example, educational innovative actions at remembering are: tohighlight; tobookmark; totapintosocialnetworking; tosearch; togoogle.

Taking into account the competence approach at elaborating educational standards, the use of B. Bloom's taxonomy in different variations becomes more and more urgent and needs correspondent changes in monitoring of students' expected results. Today the notion of education quality must be considered, based on main international documents and conventions, elaborated within international cooperation.

One of most important documents, accepted by the United Nations Organization is "Millennium development goals" [8]. Just this document declared main mankind's priorities, among which - an access to education for all as a guarantee of welfare of nations. The government of Ukraine, in its turn, accepted Millennium development goals of as a strategy of economic growth and development of the Ukrainian state. The document declared the course of Ukraine on achieving highest quality standards of education, traditionally and historically formed due to the support of educational innovations, course for democratization of education and guaranteeing of a possibility to study during the whole life.

Based on changing requirements to educators in the context of New Ukrainian school and development tendencies of professional (professional and technical) education, there appears a necessity to elaborate and to implement new monitoring methods of expected results of professional training of future specialists, especially teachers of establishments of professional and technical education.

\section{Research goal and tasks}

The goal of the study is to ground theoretically the method of organizing the psychological and pedagogical training monitoring of future teachers of professional and technical educational institutions and to give an example of its experimental implementation.

The following tasks were set for attaining this goal:

1. to ground theoretically the organizing process of the psychological and pedagogical training monitoring of future teachers of professional and technical educational institutions;

2. to separate criteria, indicators and diagnostic instruments of monitoring of components of the psychological and pedagogical competence of future teachers of professional and technical educational institutions;

3. to highlight the content of the experimental implementation of the organizing method of the psychological and pedagogical training monitoring of future teachers of professional and technical educational institutions (on the example of evaluating the formation level of cognitive and meta-cognitive abilities, skills, knowledge and understandings that take place in mastering peculiarities of the psychological and pedagogical activity).

\section{Materials and methods}

The following monitoring peculiarities are taken into account in the study.

The monitoring object is a system that concrete monitoring procedures are directed on. The main feature of such objects is their dynamics. All objects, studied by the monitoring, permanently change, develop, undergo external influences.

The monitoring object is a condition of the studied system in concrete periods of time and concrete changes within this system.

Monitoring subjects are bearers of monitoring functions, realizing them. They are conventionally divided in two big groups: subjects that give information and ones, collecting and processing it. So, subjects in the monitoring system are both institutions, structures and separate people.

The complex of monitoring indicators is a totality of primary and secondary indicators, able to provide an integral understanding about a condition of the system, qualitative and quantitative changes in it.

The toolkit of the monitoring activity is a totality of forms of statistical reporting, informational standards, questionnaires, interrogation forms and so on. At the same time instruments of the monitoring activity are different technical means, used by monitoring subjects in their activity.

Monitoring is considered, connected with the notion "quality". In pedagogy the notion "quality" is a systemic methodological category. It reflects a correspondence degree of a result to a set goal [3].

So, we consider monitoring within the experimental study as a method of controlling the productivity of the designed model of psychological and pedagogical 
training of future teachers of professional and technical educational institutionsfor evaluating the effectiveness of its functioning.

In the period of practical stage of the experimental study of the psychological and pedagogical training monitoring of future teachers of professional and technical educational institutions there were carried out: diagnostic sections (certified a condition of the psychological and pedagogical competence); realization of the designed model of this training; observation of the specificity of the studied process; measurement of intermediate results; correction of the tested model; control diagnostic sections. That is the practical stage provided three stages: ascertaining, forming and controlling.

The main task of the ascertaining experiment was to establish the real condition and level of the studied characteristics of participants of the experiment at the research moment.

The forming experiment is directed on studying the investigated phenomenon directly in the process of specially organized psychological and pedagogical training and active formation of studied features.

The control experiment was realized for comparing obtained results of the experimental group that took part in the forming experiment with ones of the control group (participated in the ascertaining experiment).

So, the monitoring had the following types:

- initial development level of each component of the psychological and pedagogical competence of PTEI future teachers;

- current, realized for checking changes in the formation of the psychological and pedagogical competence of PTEI future teachersunder the influence of organizational-pedagogical conditions of the experimental model at all its stages;

- summarizing, realized after the forming experiment and provided fixation of the formation dynamics of the psychological and pedagogical competence of PTEI future teachers.

The monitoring of the psychological and pedagogical training of PTEI future teacherswas realized stepby-step:

I stage: Goal setting and study planning

1. Determination of the research goal and tasks.

Goal: to trace the productivity of the designed model of the psychological and pedagogical training of PTEI future teachers.

Tasks:

- to reveal the initial development level of each component of the psychological and pedagogical competence of PTEI future teachers;

- to check changes in the formation of the psychological and pedagogical competence of PTEI future teachersunder the influence of organizationalpedagogical conditions of the experimental model at all its stages;

- to highlight the formation dynamics of the psychological and pedagogical competence of PTEI future teachers.

2. Determination of the research object.

The research object is the process and results of formation of the psychological and pedagogical competence of PTEI future teachers.
3. Calculation and formation of the sample.

At forming the students' sample, the district sample method was used.

4. Construction of the research graph

The term of the monitoring research conduction during the pedagogical experiment.

The pedagogical staff of higher educational institutions of Ukraine was chosen as the monitoring subject.

5 . Determination of evaluation criteria and indicators.

Structure elements of the psychological and pedagogical competence of PTEI future teacherswere used as criteria, indicators - qualitative or quantitative characteristics of a peculiarity, signs of the studied objects, that is a formation degree of a certain criterion. So, criteria were developed through the system of indicators, which changes revealed a development and formation success degree of the psychological and pedagogical competence of PTEI future teachers.

6. Choice of research methods.

Certain methods were used for monitoring the formation of the psychological and pedagogical competence of PTEI future teachersaccording to each component and chosen criteria.

II stage: Development of the toolkit

1. Development of tests and their probation.

2. Development of questionnaires and their probation.

3. Development of observation cards and their probation.

4. Preparation of instructive-methodical materials for research coordinators of all levels and research participants.

5. Choice of statistical and mathematic methods for processing and calculating obtained research results.

III stage: Research conduction structions).

1. Pilot research (preparation of participants, in-

2. Main research.

IV stage: Collection and processing of results.

$V$ stage: Analysis and interpretation of research results.

1. Generalization of statistical information.

2. Revelation of risk factors.

3. Preparation of recommendations as to the correcting work, elimination of negative factors.

Criteria, indicators and diagnostic toolkit of the monitoring of components of the psychological and pedagogical competence of future teachers:

1. Ethic values, that set an axiological vector of the future psychological and pedagogical activity.

Criteria:

Personal:moral attitude of a person to external phenomena, other people and their actions; formation of the positive motivation to the psychological and pedagogical activity(method "Value orientations" (M. Rokych) [9]; method"Evaluation of the development level of moral consciousness" (L. Kolberg) [10]).

Content and procedural:understanding of the truth of the moral values (humanistic directionality, national dignity, intelligence, life understandings, conscientiousness, honesty, truthfulness, objectivity, tolerance); moral relations with surrounding people); goal setting that cor- 
responds to motivation requirements to the psychological and pedagogical activity (method "Diagnostic of the level of moral-ethic responsibility" (I. Tymoschuk) [11]; method "Motivation of the professional activity" (by K. Zamphyr, modified by A. Renan) [12]; observation method).

Evaluative-regulatory: moral attitude of a person to him/herself and own actions; need in improving the psychological and pedagogical activity (method "Diagnostic of the level of moral-ethic responsibility" (I. Tymoschuk); method"Motivation of the professional activity" (by K. Zamphyr, modified by A. Renan); questionnaire method).

2. Cognitive and meta-cognitive abilities, skills, knowledge and understandings, taking place at mastering peculiarities of the psychological and pedagogical activity.

Criteria:

Personal: correspondence of psychophysiological peculiarities to professional requirements (psychic processes: feeling, perception, memory, thinking, imagination and attention) (testing methods: J. Raven's [13], R. Amthauer's test [14])

Content and procedural:theoretical knowledge of the academic field (flexibility, strength, understanding) (method of testing control, analysis of written and oral responses).

Evaluative-regulatory: meta-cognitive knowledge (subject's knowledge about personal learning strategies), meta-cognitive evaluation (judgment about own rational possibilities and limitations, their necessity in a concrete situation), meta-cognitive regulation (subject's modification of own thinking) (questionnaire of meta-cognitive inclusion in the activity [15]).

3. Rational and practical abilities and skills of the psychological and pedagogical activity realization.

Criteria:

Personal:presence and development level of psychological and pedagogical abilities and qualities (testing method: R. Kettel's test [16], method of solving pedagogical situations, observation method).

Content and procedural: practical and efficient use of knowledge in concrete situations (mastering of psychological and pedagogical skills) (method of solving pedagogical situations, observation method, control arrangements).

Evaluative-regulatory: self-evaluation and selfcontrol of the activity (self-evaluation and self-control methods).

4. Interpersonal abilities and skills in the process of psychological and pedagogical activity.

Criteria:

Personal:presence and development level of psychological and pedagogical abilities and qualities (testing method: R. Kettel's test, method of solving pedagogical situations, observation method).

Content and procedural:mastering of communication methods and ones of active interaction in the process of psychological and pedagogical activity realization (L. Michelson's test of communicative skills (Y. Gilbukh's adaptation) [17]; K. Tomas's questionnaire "Determination of conflict regulation" [18]; (method of solving pedagogical situations, observation method, control arrangements).
Evaluative-regulatory: self-evaluation and selfcontrol of the activity (self-evaluation and self-control methods).

At organizing and conducting the monitoring study of the psychological and pedagogicaltraining of futurePTEI teachers we observed the following principles:

- Coordination of the normative-legal, organizational and methodical support of monitoring components;

- Objectivity of obtaining and processing information that provided the maximal exclusion of subjective evaluations, taking into account all results, creation of equal conditions for all research participants in the process of checking the psychological and pedagogicaltraining effectiveness;

- Complex character of the study of the internal and external psychological and pedagogicaltraining, processing and analysis of obtained results;

- Continuity and durability of observation of a condition of the psychological and pedagogicaltraining and its influence on the formation of the psychological and pedagogicalcompetence of future PTEI teachers;

- Timeliness of obtaining, processing and using objective information about the psychological and pedagogicaltraining effectiveness;

- Promising character of the planned monitoring study and its directionality on solving the problem of attaining the optimal level of the psychological and pedagogicalcompetence of future PTEI teachers;

- Humanistic directionality of the monitoring creation of the kind, reliable, personally respectful atmosphere, maximally favorable conditions and positive microclimate;

- Openness and effectiveness of informing research results to correspondent power bodies and public.

The psychological and pedagogicalcompetence was evaluated not only by comparing obtained results with certain norms, average values, but also by juxtaposing them with ones of previous diagnostics for revealing a type of advance in the development of the psychological and pedagogicalcompetence of future PTEI teachers.

Methods for monitoring the psychological and pedagogical competence of future PTEI teachers were selected according to methodological requirements.

So, organization of the monitoring, directed just on tracing the formation dynamics of the psychological and pedagogical competence gave a possibility to evaluate the functioning effectiveness of the psychological and pedagogical training system of future PTEI teachers.

\section{Research results and their discussion}

Let's consider the monitoring of the formation level of cognitive abilities, skills, knowledge and understandings as a result of the psychological and pedagogical training of future PTEI teachers as an example [19].The pedagogical experiment was realized on the base of the higher educational institutions of Ukraine: Berdyansk state pedagogical university, KamyanetsPodilskiy national university, named after Ivan Ogyenko, Uman state pedagogical university, named after Pavlo Tichina, Zaporizhzhya national university, SHEI "Krivyj Righ national university".

The formation level of cognitive abilities, skills, knowledge and understandings of the psychological and 
pedagogicalcompetence was checked using J. Raven's and R. Amthauer's tests, complex test on psychological and pedagogical disciplines, questionnaire of metacommunicative inclusion in the activity.

J. Raven's and R. Amthauer's tests were used for revealing the correspondence of psychophysiological peculiarities to professional requirements (psychicprocesses: feeling, perception, memory, thinking, imagination and attention)(personal criterion of cognitive abilities, skills, knowledge and understandings).

J. Raven's test of progressive matrixes was used for studying thinking logicality. Indicators of accomplishingtasks of separate series were compared with the average statistic one, the difference between results, obtained in each series and control ones, obtained by the statistical processing at studying big groups was taken into account and in such a way appreciated as expected results. This difference allowed to state the reliability of the obtained results.

An intellect coefficient was considered as the general result, taking into account physical age. According to the sum of obtained points, the intellect development coefficient of a respondent was determined by transforming obtained points in IQ, taking into account his/her age and evaluating the intellect level by the scale of rational abilities.

The results of this test were confirmed by $\mathrm{R}$. Amthauer's intellect structure test. Subtest №1 «Addition of sentences» determined a reserve of knowledge in different branches: geography, history, biology and so on (it mainly fulfils a motivation function, causes interest to accomplish the following subtests). Subtest № 2 «Exclusion of a word» was used for studying the analyticsynthetic activity of students (obtained data allowed to judge about the respondents' ability to separate general signs and properties of subjects or notions, their ability to compare, to pass from visually active comparing forms to abstract ones). Subtest № 3 «Analogues» determined the development level of verbal-logic thinking (obtained data allowed to judge about respondents' potential possibilities). Subtest № 4 «Generalizations» determined the development level of abstract thinking, vocabulary richness. Subtest № 5 «Arithmetic tasks» determined the ability to mathematical analysis and synthesis, logic conclusion, mathematical generalization. Subtest № 6 «Numeric lines» determined mainly analytic-synthetic mathematic abilities. Subtest № 7 «Spatial understanding» revealed the ability to operate with two-dimensional images. Subtest No. 8 «Spatial generalization» determined the development level of visually active thinking. Subtest No. 9 «Memory, mnemonic abilities» revealed the development level of verbal short-term memory.

At the beginning of the experiment intellectual possibilities of students from EG and CG had been mainly at the middle level and didn't practically change after it, but it cannot be explained by an interval discrepancy of attaining the next level. In general EG indices indicate more progressive positive dynamics (low level $(-3.12 \%)$; middle level $(-3.12 \%)$; sufficient level $(+4.15 \%)$; high level $(+2.09 \%)$ ) comparing with CG (low level $(-2.08 \%)$; middle level $(+2.08 \%)$; sufficient level $(-1.04 \%)$; high level $(+1.04 \%))$
The complex test on psychological and pedagogical disciplines was used for revealing psychological and pedagogical knowledge (flexibility and strength) and understanding of the essence of the psychological and pedagogical activity of future PTEI teachers (content and procedural criterion of cognitive abilities, skills, knowledge and understandings).

The measurement was in determining the knowledge level by accomplishing the test of 20 questions. A characteristic (sign) of future PTEI teachers is a number of correct answers. The evaluation was realized by the levels: low (number of correct answers is less or equal5); middle (number of correct answers is more 5, but less or equal 10); sufficient (number of correct answers is more 10 , but less or equal 15); high (number of correct answers is more 15).Based on the data, the number of higher education applicants, who got a point, correspondent to a certain diapason, was calculated in percent ratio.

According to the data at the end of the experiment, essential improvements were fixed in the experimental group. The number of EG students, demonstrated the high level increase by $18.23 \%$, sufficient - by $23,44 \%$. In CG, improvements at these levels were absent. Instead of it, the essential number of CG students $14.07 \%$ passed from the low level to the middle one. In EG the number of students with the low level decreased by $13.54 \%$, middle - by $28.13 \%$.

The goal of using the questionnaire of metacognitive inclusion in the activity is to reveal metacognitiveabilities, skills, knowledge and understandings (evaluative-regulatory criterion of cognitive abilities, skills, knowledge and understandings).

The evaluation was realized in the diapason:

- low level - less 65 points,

- middle level - 66-129 points,

- sufficient level - 130-194 points,

- high level - 195-260 points.

At the beginning of the experiment metacognitive inclusion in the activity of CG and EG students not almost differed. At the end of the experiment metacognitive knowledge (subject's knowledge about personal learning strategies), meta-cognitive evaluation (judgment about own rational possibilities and limitations, their necessity in a concrete situation) and meta-cognitive regulation (subject's modification of own thinking) are demonstrated more by EG (low level decreased by $11.98 \%$, middle level-by $11.98 \%$, sufficient level increased by $15.1 \%$, high - by $8.86 \%$ ) comparing with CG (low level decreased by $6.25 \%$, middle level increased by $2.08 \%$, sufficient level - by $2.09 \%$, high by $2.08 \%$ ).

So, the average formation result of the component of the psychological and pedagogical competence - cognitive and meta-cognitive abilities, skills, knowledge and understandings of future PTEI teachers testified to the most considerable qualitative changes at the middle formation level of cognitive and meta-cognitive abilities, skills, knowledge and understandings, conditioned by the decreased number of students of a certain category during the pedagogical experiment by $14.41 \%$ in EG. The sufficient and high formation levels of this component 
also demonstrated positive qualitative changes: increase of the number of students in the control (by $0.35 \%$ and $1.04 \%$ respectively) and experimental (by $14.23 \%$ and $9.73 \%$ respectively) groups. The least dynamics of qualitative changes of this component formation level was fixed in the category «low level» in EG $-9.55 \%$.

The comparative analysis of absolute mean values of qualitative changes of the formation level of cognitive and meta-cognitive abilities, skills, knowledge and understandings in the control and experimental groups gave a possibility to make a conclusion that the positive dynamics of qualitative changes in CG (mean) $=3.74 \%$ ) is conditioned by the traditional psychological and pedagogical training, and in $\mathrm{EG}$ (mean) $=11.98 \%$ ) - is a result of the students' psychological and pedagogical training by the experimental model.

The obtained results of the experimental study were confirmed by using methods of mathematical statistics, especially calculation of Pearson non-parametric criterion $-\chi^{2}$. Statistical hypotheses were formulated for that:

$\mathrm{H}_{0}$ : the experimental model of the system of psychological and pedagogical trainingof future PTEI teachers doesn't influence the formation level of cognitive and meta-cognitiveabilities, skills, knowledgeand understandings ofthe psychological and pedagogical competence of these specialists, and the obtained results are casual.

$\mathrm{H}_{1}$ : qualitative changes of the formation level of cognitive and meta-cognitiveabilities, skills, knowledgeand understandings of the psychological and pedagogical competence of future PTEI teachers are conditioned by the influence of the experimental model of the system of psychological and pedagogical training.

The obtained value of Pearson criterion is $\chi_{\text {exp }}^{2}=20.31$, where $\chi_{\text {exp }}^{2}>\chi_{\text {crit }}^{2}(20.31>7.8)$. The experimental value of Pearson criterion is a base for denying $\mathrm{H}_{0}$ and accepting the alternative hypothesis $\mathrm{H}_{1}$ about the influence of the model of the system of psychological and pedagogical trainingof future PTEI teachers on the formation of cognitive and meta-cognitiveabilities, skills, knowledgeand understandings of the psychological and pedagogical competence.

The offered study allows to solve problems with staff of labor migration at the level of providing highquality professional education and learning, especially in the context of getting competences for personal and professional self-realization, career growth during the whole life by higher education applicants. The quality correspondence of professional education and learning to labor market demands and personal needs of future specialists will provide an increase of competitiveness, so the stable motivation of a qualification applicant.

The organizing method of monitoring the psychological and pedagogical trainingof future teachers of pro- fessional and technical educational institutions may be used as a quality indicator for educational programs as to attaining expected formation results of components of the psychological and pedagogical competencein both higher education applicants and specialists of production or service sector, involved in the professional-pedagogical activity.

\section{Conclusion}

1. Monitoring organization of the psychological and pedagogical trainingof future teachers of professional and technical educational institutionsis realized in five stages:

-I stage -goal setting and research planning (determination of the goal and tasks of the study; determination of the research object; calculation and formation of the sample; construction of the research graph; determination of evaluation criteria and indicators; choice of the research methods);

-II stage -development of the toolkit (preparation of instructive-methodical materials for research coordinators of all levels and research participants; choice of statistical and mathematic methods for processing and calculating obtained research results);

-III stage - conduction of the research;

-IV stage -collection and processing of the results;

$-\mathrm{V}$ stage -analysis and interpretation of the research results.

2. Based on the determined components of the psychological and pedagogical competence, three criteria have been separated: personal, content and procedural, evaluative regulatory. At that each criterion is a totality of several indicators, characterizing the most essential and necessary manifestations of components of the psychological and pedagogical competenceof future teachers of professional and technical educational institutions.

3. The results of the experimental implementation of the monitoring organization of the psychological and pedagogical trainingof future teachers of professional and technical educational institutions (on the exampleof checking the formation level of cognitive and metacognitiveabilities, skills, knowledgeand understandings, taking place in mastering peculiarities of the psychological and pedagogicalactivity) indicate the validity and adequacy of research instruments and reliability of the obtained data.

4. The monitoring organization of the psychological and pedagogical trainingof future teachers of professional and technical educational institutionsfavors the timely correction of professional competences and readiness to competitiveness at the native labor market for preventing labor migration of these specialists.

\section{References}

1. Pro zatverdzhennia Kontseptsii rozvytku pedahohichnoi osvity: nakaz MON Ukrainy No. 776. 16.07.2018. URL: https://mon.gov.ua/ua/npa/pro-zatverdzhennya-koncepciyi-rozvitku-pedagogichnoyi-osviti (Last accessed: 21.01.20)

2. Lokshyna O. I. Stanovlennia ta rozvytok monitorynhu yakosti osvity: svitovyi vymir // Monitorynh yakosti osvity: svitovi dosiahnennia ta ukrainski perspektyvy. Kyiv: K.I.S., 2004. P. 28-29.

3. Vymiriuvannia v osviti: textbook / ed. by Avramenko O. V. Kirovohrad: «KOD», 2011.360 p.

4. Bloom B. S., Krathwohl D. R. Taxonomy of Educational Objectives: The Classification of Educational Goals, by a committee of college and university examiners. Handbook I: Cognitive Domain. New York: Longmans, Green, 1956. 403 p. 
5. Bloom B. S., Hastings J. T., Madaus G. F. Handbook on formative and summative evaluation of student learning. New York: McGraw-Hill, 1971. 923 p.

6. A Taxonomy for Learning, Teaching, and Assessing: A Revision of Bloom's Taxonomy of Educational Objectives / ed. by Anderson L. W., Krathwohl D. R. et. al. New York: Longman, 2001. 352 p.

7. Churches A. Bloom's Digital Taxonomy. 2007. 44 p.

8. Millenium Development Goals. Ukraine. Ministry of Economy and European Integration of Ukraine. Kyiv, 2003. 27 p.

9. Morhun V. F., Titov I. H. Osnovy psykholohichnoi diahnostyky: textbook. Kyiv: Vydavnychyi Dim «Slovo», 2009. 464 p.

10. Metodika otsenki urovnia razvitiia moralnogo soznaniia (Dilemmy L. Kolberga) / ed. by Dermanova I. B. // Diagnostika emotsionalno-nravstvennogo razvitiia. Saint-Peterburg, 2002. P. 103-112.

11. Oprosnyk DUMEOLP - dyahnostyka urovnia moralno-etycheskoi otvetstvennosty lychnosty Y. H. Tymoshchuka. URL: http://tpcollege.ru/docs/psysluzhba/3moralnoetich.pdf (Last accessed: 21.01.20) 2001. $560 \mathrm{p}$.

12. Psykholohiia: textbook / Trofimov Yu. L., Rybalka V. V., Honcharuk P. A. et. al.; ed. by Trofimov Yu. L. Kyiv: Lybid,

13. Metodika izucheniia logichnosti myshleniia (Progressivnye matritsy Ravena). URL: http://www.miu.by/kaf_new/mpp/129.pdf (Last accessed: 21.01.20)

14. Test struktury intellekta R. Amtkhauera. URL: http://vsetesti.ru/443/ (Last accessed: 21.01.20)

15. Karpov A. V., Skitiaieva I. M. Psykholohiia metakohnityvnykh protsesiv osobystosti. 2005. URL: http://psih.pp.ua/ (Last accessed: 21.01.20)

16. Metodika mnogofaktornogo issledovaniia lichnosti R. Kettella. URL: http://psycabi.net/testy/293-16-faktornyjlichnostnyj-oprosnik-r-b-kettella-metodika-mnogofaktornyj-oprosnik-kettella-test-kettela-187-voprosov-test-ketela-16-pf (Last accessed: 21.01 .20$)$

17. Test kommunikativnykh umenii L. Mikhelsona. URL: https://sites.google.com/site/test300m/tku (Last accessed:

18. Vikova psykholohiia: textbook / ed. by Klochko V. Ye. 2003. URL: http://medbib.in.ua/vozrastnaya-psihologiya782.html (Last accessed: 21.01.20)

19. Kryvylova O. A. The projection of psychological and pedagogical training of future professional and technical educational establishments' teachers: doctor's theses. Khmelnytskyi: Khmelnytska humanitarno-pedahohichna akademiia, 2018. 546 p.

Received date 27.01.2020

Accepted date 17.02.2020

Published date 31.03.2020

Olena Kryvylova, Doctor of Pedagogical Sciences, Associate Professor, Department of Professional Education, Labor Training and Technologies, Berdiansk State Pedagogical Univarsity, Schmidta str., 4, Berdiansk, Zaporizhzhia region, Ukraine, 71100

E-mail: Krivileva.lena@gmail.com 